\title{
Two Cases of Gastric Volvulus in Neonates
}

\author{
Min Yeong Kim, MD, Moon Sung Park, MD, PhD, and Jang Hoon Lee, MD, PhD \\ Department of Pediatrics, Ajou University Hospital, Ajou University School of Medicine, Suwon, Korea
}

\section{ABSTRACT}

Gastric volvulus in neonates is an extremely uncommon disorder, which is challenging to diagnose because of its non-specific clinical manifestations. Early diagnosis of gastric volvulus is important to avoid life-threatening complications, such as gastric ischemia, necrosis, and perforation. A definitive diagnosis could be made with radiological upper gastrointestinal series. In this report, we present two cases of neonate gastric volvulus, which were confirmed by radiological upper gastrointestinal series, and the patients underwent surgical treatment.

Key Words: Gastric volvulus; Neonate; Infant, newborn

\section{서론}

위염전은 위의 일부 또는 전체가 180 도 이상 비정상적인 회전을 하여 발생하며 위의 장폐색 을 일으키는 드문 질환으로 대부분 성인에게서 나타나며 신생아 위염전은 매우 흔치 않게 발생 한다 ${ }^{1,2)}$. 위염전으로 인하여 발생할 수 있는 장의 허혈, 꼬임, 괴사, 천공 등의 합병증을 막기 위 해 빠른 진단과 적절한 치료가 중요하나 임상적 증상이 특이적이지 않아 영상학적 평가를 필요 로 한다 ${ }^{3)}$. 신생아 시기에 드물게 발생하는 위염전의 국내 사례는 Choi 등ㅎㅇㅇㅣ 보고한 횡경막 내 장탈출이 동반된 장간막축성 위염전 케이스 1 례에 불과하며, 그 외 신생아 장기축성 위염전 사 례 보고는 없었다. 저자들은 본원에서 신생아 장기축성 위염전을 진단하고 성공적으로 치료한 2 례를 경험하였기에, 임상적 증상 및 영상학적 특징에 대하여 문헌고찰과 함께 보고하고자 한다.

\section{증례}

\section{1. 증례 1}

생후 4일 된 남아가 구토, 상복부 팽만, 무호흡을 주소로 본원에 입원하였다. 환아는 산전 진 찰에서 특이 소견 없었고, 재태 연령 35 주 1 일, 체중 $2,245 \mathrm{~g}$, 산모 임신성 고혈압에 의해 제왕절 개로 쌍둥이 중 첫째로 태어났다. 출생 직후 호흡곤란이 있어 기관 삽관 및 인공호흡기 치료를 하였고, 증상이 호전되는 추세를 보여 생후 1 일째 기관 발관하였다. 정상적인 태변 배출이 있었 고, 수유는 경구 및 경관으로 $10 \mathrm{cc}$ 시작하였으나, 생후 2 일째 무호흡 증상이 있어 지속적 양압 환기 치료하였으며, 반복적인 구토, 지속되는 상복부 팽만으로 생후 4 일째 본원에 전원되었다.
Received: 16 August 2020

Revised: 28 September 2020

Accepted: 11 October 2020

Correspondence to: Jang Hoon Lee, $\mathrm{MD}, \mathrm{PhD}$

Department of Pediatrics, Ajou University Hospital, Ajou University School of Medicine, 164 World cup-ro, Yeong tong-gu, Suwon 16499, Korea

Tel: +82-31-219-5167

Fax: +82-31-219-5169

E-mail: neopedlee@gmail.com

Copyright(c)

By Korean Society of Neonatology.

All right reserved.

This is an Open-Access article distributed under the terms of the Creative Commons At tribution Non-Commercial License (http:// creativecommons.org/licenses/by-nc/4.0), which permits unrestricted non-commercial use, distribution, and reproduction in any medium, provided the original work is pro perly cited. 
내원 당시 이학적 소견에서 체중 $2,085 \mathrm{~g}$, 심박수 110 회/분, 호흡 수 54 회/분, 체온 $36.6^{\circ} \mathrm{C}$ 이었으며, 흥부 진찰에서 간헐적인 빠른 호 흡과 흥골 함몰 소견이 있었고, 복부 진찰에서 상복부 팽만이 관찰 되었다.

일반혈액검사에서 백혈구 $4,200 / \mu \mathrm{L}$, 혈색소 $13.9 \mathrm{~g} / \mathrm{dL}$, 혈소판 수 $224,000 / \mu \mathrm{L}$ 이었고, 전해질 수치는 나트륨 $135 \mathrm{mEq} / \mathrm{L}$, 칼륨 4.8 $\mathrm{mEq} / \mathrm{L}$, 염소 $101 \mathrm{mEq} / \mathrm{L}$ 이었다. 혈청생화학검사에서 아스파르테이 트아미노전달효소 $10 \mathrm{U} / \mathrm{L}$, 알라닌아미노전달효소 <5 U/L, 총빌리 루빈 $5.2 \mathrm{mg} / \mathrm{dL}$ 이었고, 동맥혈 가스분석에서 $\mathrm{pH}$ 7.396, $\mathrm{pCO}_{2} 42.4$ $\mathrm{mm} \mathrm{Hg}, \mathrm{pO}_{2} 120.5 \mathrm{~mm} \mathrm{Hg}, \mathrm{HCO}_{3} 25.4 \mathrm{mmol} / \mathrm{L}$, base excess 0.4 $\mathrm{mmol} / \mathrm{L}$ 로 특이 소견 없었다.

입원 이후 하루 2-3차례 무호흡 증상이 있어 고유량 비강 캐뉼라 로 산소 투여하였고, 경관으로 $5 \mathrm{cc}$ 혼합 수유 시 구토를 지속적으로 하여 금식하며 정맥 영양 유지하였다. 증상 감별을 위해 시행한 단 순 복부 촬영에서는 위의 비정상적인 굽이 및 쌍기포(gastric double bubble) 소견이 의심되었고(Figure 1A), 복부 초음파에서도 위의 부 분적 막힘 소견이 의심되어 상부 위장관 조영술을 시행하기로 하였 다. 생후 6일째 시행한 상부 위장관 조영술에서 위 팽창 소견과 함 께 큰굽이가 위의 위쪽에 위치한 비정상 소견이 관찰되어 장기축성 위염전으로 진단되었다(Figure 2). 진단 당일 본원 소아외과에서 수 술을 시행하였으며, 수술 소견상 선천적 구조 이상은 동반되지 않았 고, 위 전벽 고정술, 임시적 위창냄술을 시행하였다. 수술 후 단순 복 부 촬영 결과에서 정상적인 위 굽이 소견 확인되었으며(Figure 1B), 단계적으로 경구 섭취를 늘려갔고 구토 없이 정상적인 칼로리 보충 이 가능하였다. 특이 합병증 없이 퇴원하였고, 20 개월의 추적 관찰 동안 재발 없이 정상적으로 성장 및 발달하였다.

\section{2. 증례 2}

생후 2 일 된 여아가 구토, 상복부 팽만, 혈변을 주소로 본원에 입 원하였다. 환아는 산전 진찰에서 특이 소견이 없었고, 재태 연령 36 주 5일, 체중 $2,390 \mathrm{~g}$, 산모 조기양막파수로 인해 제왕절개로 출생하 였다. 출생 후 정상적인 태변 배출이 있었고 경구로 $10 \mathrm{cc}$ 혼합 수유 하였으나, 생후 1 일에 발생한 수유 곤란, 구토, 혈변이 지속되어 본 원에 전원되었다.

본원 입원 당시 체중은 $2,175 \mathrm{~g}$ 이었으며, 심박수 148 회/분, 호흡 수 44 회/분, 체온 $36.6^{\circ} \mathrm{C}$ 였으며 흥부진찰에서 특이 소견은 없고, 복 부 진찰에서 상복부 팽만이 관찰되었다. 일반혈액검사에서 백혈구 $6,900 / \mu \mathrm{L}$, 혈색소 $14.8 \mathrm{~g} / \mathrm{dL}$, 혈소판 수 $332,000 / \mu \mathrm{L}$ 이었고, 전해질
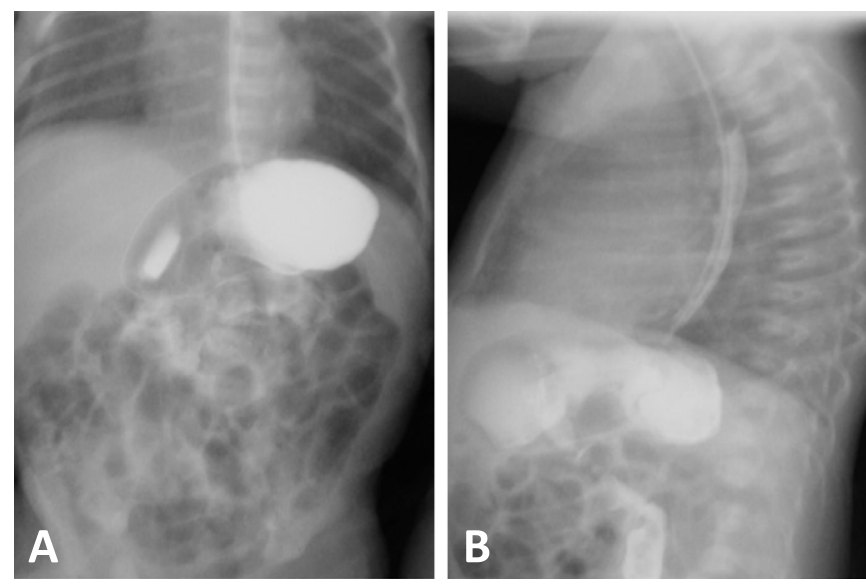

Figure 2. Case 1. Upper gastrointestinal series showing a distended stomach with the abnormal superior position of the greater curvature. (A) Frontal view (B) Lateral view.
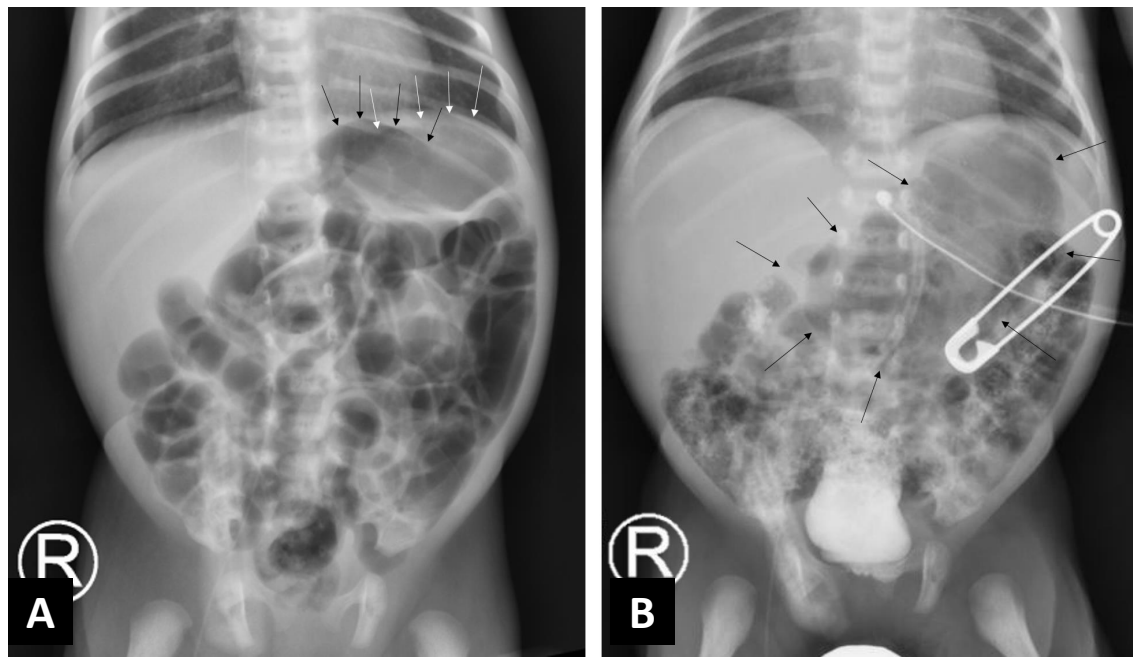

Figure 1. Case 1. Simple supine abdominal X-ray. (A) Gaseous distension of the bowel loops and suspicious abnormal curvature of the gaseous stomach along with a double bubble sign were seen (black arrows: the first bubble in the distal portion of the stomach [suspicious greater curvature]; white arrows: the second bubble). (B) Normal gastric curvature after surgery. 
수치는 나트륨 $140 \mathrm{mEq} / \mathrm{L}$, 칼륨 $4.4 \mathrm{mEq} / \mathrm{L}$, 염소 $106 \mathrm{mEq} / \mathrm{L}$ 이었다. 혈청생화학검사에서 아스파르테이트아미노전달효소 $20 \mathrm{U} / \mathrm{L}$, 알라 닌아미노전달효소 $20 \mathrm{U} / \mathrm{L}$, 총빌리루빈 $8.4 \mathrm{mg} / \mathrm{dL}$ 이었고, 분변잠혈 검사에서 양성으로 확인되었다.

내원 직후 첫 대변에서는 혈변이 육안으로 관찰되지 않았으나 잠 혈 여부를 확인하기 위해 과산화수소를 적용하였고 양성 확인되었 으며, 경구 및 경관으로 분유 수유 시 소화되지 않은 잔량이 있어 금 식을 유지하였다. 단순 복부 촬영 및 복부 초음파에서 특이 소견이 발견되지 않아 생후 3 일째 다시 경구 및 경관으로 혼합 수유를 시도 하였다. 수유 증량 시 잔량, 구토가 지속되었으며, 간헐적으로 혈변 이 있어 맥켈 스캔을 시행하였으나 이상 소견이 발견되지 않았다. 모유 수유 시에는 혈변이 호전되었으나 분유 수유 시 혈변이 증가되 어 시행한 우유 알레르기검사 결과 혈변은 알레르기성 직결장염에 의한 증상으로 판단하였다. 따라서 일반 분유 수유를 중단하고 완전 단백가수분해분유로 변경한 이후 혈변이 호전되었다. 또한, 반복되 는 구토에 대한 감별을 위하여 생후 14 일 상부 위장관 조영술을 시 행하였고, 큰굽이가 위의 위쪽에 위치한 비정상 소견이 관찰되어 장 기축성 위염전으로 진단되었다(Figure 3). 진단 당일 본원 소아외과 에서 수술을 시행하였으며, 수술 소견상 선천적 구조 이상은 동반되 지 않았고, 염전된 위를 정복 후 위고정술과 임시적 위창냄술을 시 행하였다. 수술 후 특별한 문제 없이 구토가 호전되어 퇴원하였으 며 12 개월 동안의 추적 관찰 동안 재발 없이 정상적으로 성장과 발 달하였다.

\section{고찰}

위염전은 장축 혹은 단축을 따라 위가 180 도 이상으로 회전하여 장 폐쇄를 일으키는 질환으로, 신생아에게서 발견되는 사례는 매우
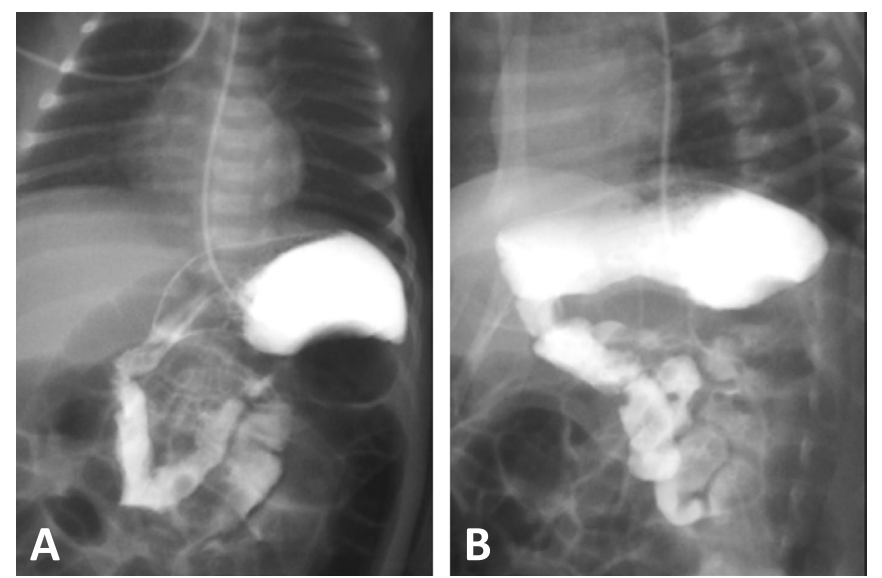

Figure 3. Case 2. Upper gastrointestinal series showing the abnormal superior position of the greater curve. (A) Frontal view (B) Lateral view.
흔치 않다 ${ }^{2,5}$. Berti의 부검 소견을 통해 1866년 위염전에 대한 첫 보 고가 있었으며, Berg가 1897년 횡경막 내장탈출과 위염전이 동반된 환자를 처음으로 외과적 치료를 하였으며 Oltmann이 1899년 첫 소 아 환자 사례를 소개하였다 ${ }^{6,7)}$. 소아, 특히 신생아 위염전 환자는 전 세계적으로 드물며 국내에서도 Choi 등)이 보고한 횡경막 내장탈출 이 동반된 장간막축성 위염전 1 례만 있었다. 국내에서 신생아 시기 에 진단된 1 차성 장기축성 위염전이 보고된 사례는 없었기에 본원 신생아집중치료실에서 경험한 신생아 장기축성 위염전 2례에 대하 여 보고하였다.

몇 가지 분류법을 통하여 위염전을 구분할 수 있는데, 해부학적으 로는 염전 되는 회전축 방향에 따라 장기축성(organoaxial type), 장 간막축성(mesenteroaxial type) 및 혼합성(combined type)으로 나 눌 수 있다. 장기축성 위염전은 위가 위식도 경계와 위유문부를 잇 는 위의 장축을 중심으로 회전하여 발생하며, 큰굽이가 작은굽이 위 쪽에 위치하는 특징을 보이게 되고 위염전의 약 $60 \%$ 를 차지한다. 장 간막축성 위염전은 약 $30 \%$ 를 차지하며, 위의 큰굽이와 작은굽이 각 각의 중앙을 잇는 단축을 중심으로 회전하여 발생하게 되고, 위전정 부와 위유문부가 위식도 경계의 앞, 위에 위치하게 된다(Figure 4). 장기축성과 장간막축성이 혼합되어 발생하는 경우는 약 $10 \%$ 미만 에서 관찰된다 ${ }^{1,7)}$.

병인에 따라서는 1 차성(특발성) 또는 2 차성으로 분류되며, 1 차성 은 복강 내 장기의 이상 소견 없이 종양, 유착 또는 위를 지지하는 인 대의 이상 때문에 염전이 일어나는 것을 말한다. 위는 4 가지 인대( 위결장, 위간, 위횡경막, 위비장)에 의해 복벽에 고정된다. 위유문 및 위식도 경계와 함께 이들 인대는 위를 고정시켜 회전 이상을 막 는 역할을 하게 되는데, 위 인대의 무 발생, 신장 또는 파괴 등으로

A
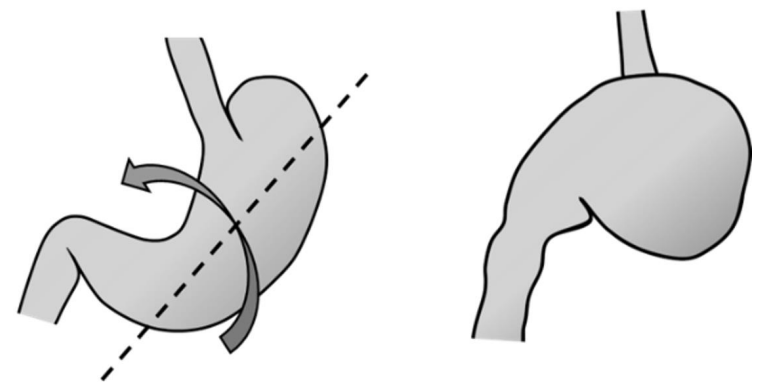

B
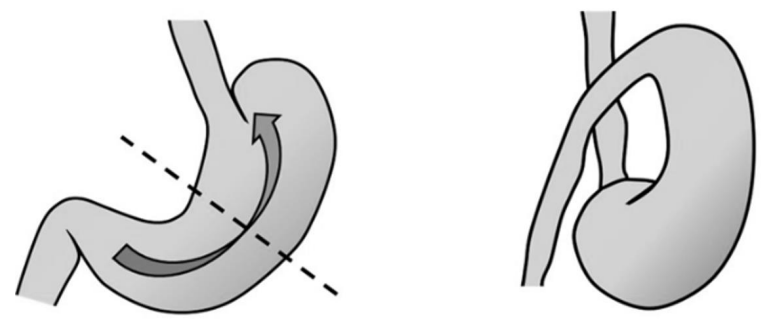

Figure 4. Schematic representation of gastric volvulus. (A) Organoaxial type. (B) Mesenteroaxial type. 
인하여 위가 지지되지 않는다면 1차성 위염전을 유발하게 된다. 반 면 2차성 위염전은 횡경막, 비장같은 인접 장기 및 위의 해부학적 구 조 이상에 의해 발생하며, 주로 횡경막 탈장, 횡경막성 내장전위, 식 도 주위 탈장, 부유 비장 등을 흔한 원인으로 볼 수 있다 ${ }^{5,79)}$. 신생아 시기의 2 차성 위염전 사례들에 따르면 횡경막성 내장전위, 횡경막 탈장이 동반 질환으로 보고된바 있다 ${ }^{4,10,11)}$.

위염전의 임상 증상은 장의 회전 및 폐쇄 정도, 발현 속도에 따라 다양하게 나타날 수 있으며, 임상 증상에 따라서는 급성과 만성 위 염전으로 구분할 수 있다 ${ }^{1,7,12-14)}$. 특히, 소아의 경우 위염전의 임상 증상은 비특이적인 경우가 많으나 Cribbs 등'에 따르면, 소아에서 급성 위염전의 경우 구토(75\%), 상복부 팽만(47\%), 복통(34\%)이 주 된 증상으로 나타났으며, 급성 호흡곤란(11\%)과 무호흡(8\%)의 증 상을 보이기도 했다. 만성 위염전의 경우 구토(71\%), 상복부 팽만 $(34 \%)$, 성장 장애(30\%), 복통( $12 \%)$ 등의 증상이 나타났다.

소아의 경우 성인과 달리 장기축성의 발생 빈도가 더 적고, 횡 경막 내장탈출 등을 동반하는 2차성 위염전이 주로 보고되었지만 $6,15,16)$, 본 증례에서는 소아에서 흔치 않은 장기축성, 1 차성 위염전을 진단하였다. 한편, 증례 1은 급성 위염전으로 의심할 수 있는 구토, 상복부 팽만과 함께 반복적인 호흡곤란 및 무호흡 증상이 동반되었 으며, 증례 2는 호흡 문제없이 간헐적인 구토, 상복부 팽만 등을 특 징으로 하는 만성 위염전의 증상을 나타내었다.

Cribbs 등 ${ }^{1)}$ 에 의하면 소아 위염전 중 급성은 신생아에서 증상 발 생 된 경우가 $21 \%$, 생후 1년 내 발생한 경우가 $37 \%$ 였으며, 만성의 경우 1 년 내 발생한 경우가 $71 \%$ 에 해당하는 등 대부분의 소아 위염 전 증상이 1세 이전에 나타났다. Duman 등르는 신생아 위염전 임상 증상의 첫 발현 후 진단까지의 기간이 2 일에서 12 일(평균 5.5 일) 소 요되었다고 보고하였으며, El-Gohary와 Etiaby ${ }^{10)}$ 는 출생 직후 발생 한 증상에 대해 생후 5 개월에 위염전을 진단하기도 하였다. 본 논 문의 환아에서는 증례 1 의 경우 출생 직후 호흡곤란 증상이 나타났 고 생후 2 일에 구토가 발생하였으며 생후 6일에 진단되었다. 증례 2 의 경우 생후 1 일에 구토가 발생하였으며 생후 14 일에 진단되었다.

증상의 비특이성과 적은 발생 빈도로 인해 위염전을 진단하는 것 이 어려우므로, 보통 임상적 증상과 함께 영상학적 평가를 필요로 하게 된다. 단순 복부 촬영에서 위염전을 시사하는 소견으로는 비 위관 삽입에도 지속되는 비정상적인 위의 팽만, 위의 쌍기포, 수평 면 상에 놓인 팽창된 위, 상복부에서 관찰되는 공기액체층이 있달. 복부초음파는 위염전 외의 다른 질환을 배제하기 위해 시행될 수 있 고, 위의 비정상적인 회전 소견이 나타나기도 하며, 복부 전산화단 층촬영이나 자기공명영상에서 공기액체층과 팽창된 위 소견이 관 찰될 수 있닿. 상부 위장관 조영술은 위염전 진단을 위한 유용한 영 상적 검사로 사용되며 바륨 조영제가 위십이지장을 통과하지 못하 거나, 비정상적으로 회전된 위의 형태가 관찰되어 확진 검사로 이용 하게 된다 ${ }^{1,7)}$.
본 논문에서 증례 1 의 단순 복부 촬영 결과 위의 비정상적인 굽이 및 쌍기포 소견이 보였고, 복부 초음파에서는 위의 부분적 막힘 소 견이 의심되어 확진을 위해 상부 위장관 조영술을 시행하였고, 큰굽 이가 위의 위쪽에 위치한 비정상 소견을 보였다. 증례 2는 단순 복 부 촬영과 복부 초음파에서 저명한 이상 소견이 없었으나, 상부 위 장관 조영술에서 큰굽이가 위의 위쪽에 위치한 비정상 소견이 관찰 되었다.

위염전이 경도, 중등도의 증상을 보이는 경우 보존적 치료를 통한 자연 정복을 기대해볼 수 있으나, 중증도 이상의 증상이거나 증상이 반복되는 경우 수술적 치료를 고려해야 한다. 수술적 치료의 경우, 괴사 부위가 있는 경우 이를 절제하고 선행 원인이 동반되었으면 이 를 제거해야 한다. 또한 위염전을 정복시키고 재발을 방지하기 위해 위고정술을 시행하며 위창냄술을 고려할 수 있다 $1,7,9,15,16)$.

본 논문의 증례 1 의 환아에서는 중증도 이상의 급성 증상을 보여, 위염전 진단 직후 위 전벽 고정술, 임시적 위창냄술을 시행하였고, 증례 2의 경우 경증의 구토가 주 증상이었으나 구토가 반복적으로 지속되어 수술적 치료가 필요하다고 판단하여 위 전벽 고정술, 임시 적 위창냄술을 시행하였다.

$\mathrm{da}$ Costa와 Saxena ${ }^{9}$ 에 의하면 소아 환자군에서 위염전으로 인한 사망률은 적절한 치료를 받지 못하고 사망한 경우를 포함하여 $6.4 \%$ 이었고, 치료 후 합병증 발생률은 $18.9 \%$ 이었다. 신생아 시기에 위염 전 증상이 발생한 사례에서는 대부분의 환자들이 수술 후 좋은 예후 를 보였으나, 일부에서는 합병증으로 창상감염과 일시적인 장폐색 을 보였으면) ${ }^{4}$ 사망이 드물게 보고되었다 ${ }^{10)}$. 본 논문에서 증례 1 의 환아는 수술 후 20 개월 동안, 증례 2 의 환아는 수술 후 12 개월 동안 추적 관찰하였으며 특이 합병증 없이 좋은 예후를 보였다.

신생아 군에서 위염전은 매우 드물게 발생하는 질환이나, 위염전 으로 진단된 신생아 사례들을 종합해보면 구토, 상복부 팽만, 수유 곤란, 호흡곤란 등의 비특이적인 임상 증상을 보였다,2,4,-11,15,16) 따라 서 원인을 알 수 없는 상기 증상들이 지속되는 경우 위염전을 의심 해보아야 하며, 또한 단순 복부 촬영에서 비위관 삽입에도 지속되는 비정상적인 위의 팽만, 위의 쌍기포, 수평면 상에 놓인 팽창된 위, 상 복부에서 관찰되는 공기액체층 소견이 있는 경우 위염전의 가능성 에 대하여 고려해야 한다. 상기 임상 증상 또는 영상학적 소견을 보 이는 환아에 대한 위염전의 확진을 위하여 상부위장관 조영술을 통 한 조기 감별을 강조하는 바이다.

\section{ARTICLE INFORMATION}

\section{Ethical statement}

This study was approved by the Institutional Review Board of Ajou University Hospital (IRB No. AJIRB-MED-EXP-20-285). 
Informed consent was waived by the board due to a retrospective nature of our study.

\section{Conflicts of interest}

No potential conflict of interest relevant to this article was reported.

\section{Author contributions}

Conception or design: M.Y.K., J.H.L.

Acquisition, analysis, or interpretation of data: M.Y.K., M.S.P., J.H.L.

Drafting the work or revising: M.Y.K., M.S.P., J.H.L.

Final approval of the manuscript: J.H.L.

\section{ORCID}

Min Yeong Kim https://orcid.org/0000-0003-1177-7387

Jang Hoon Lee https://orcid.org/0000-0003-4765-9948

\section{Acknowledgments}

None

\section{REFERENCES}

1. Cribbs RK, Gow KW, Wulkan ML. Gastric volvulus in infants and children. Pediatrics 2008;122:e752-62.

2. Duman L, Savas MC, Buyukyavuz BI, Akcam M, Sandal G, Aktas AR. Early diagnostic clues in neonatal chronic gastric volvulus. Jpn J Radiol 2013;31:401-4.

3. Trecroci I, Morabito G, Romano C, Salamone I. Gastric volvulus in children: a diagnostic problem: two case reports. J Med Case Rep 2016;10:138.
4. Choi SO, ParkWH, Kang JS. Gastric volvulus in the newborn and infancy. Ann Surg Treat Res 1986;31:236-43.

5. Darani A, Mendoza-Sagaon M, Reinberg O. Gastric volvulus in children. J Pediatr Surg 2005;40:855-8.

6. Vaghela MM, Sinha AK, Kumar B, Kumar P. Chronic recurrent vomiting associated with primary gastric volvulus in infant: a case report and review of literature. Afr J Paediatr Surg 2017;14: 12-4.

7. Akhtar A, Siddiqui FS, Sheikh AA, Sheikh AB, Perisetti A. Gastric volvulus: a rare entity case report and literature review. Cureus 2018;10:e2312.

8. Rashid F, Thangarajah T, Mulvey D, Larvin M, Iftikhar SY. A review article on gastric volvulus: a challenge to diagnosis and management. Int J Surg 2010;8:18-24.

9. da Costa KM, Saxena AK. Management and outcomes of gastric volvulus in children: a systematic review. World J Pediatr 2019; 15:226-34.

10. El-Gohary MA, Etiaby A. Gastric volvulus in infants and children. Pediatric Surg Int 1994;9:486-8.

11. Chattopadhyay A. Neonatal gastric volvulus: another cause of "Mucousy baby" with gasless abdomen. Indian J Pediatr 2010; 77:691-2.

12. Al-Salem AH. Intrathoracic gastric volvulus in infancy. Pediatr Radiol 2000;30:842-5.

13. Porcaro F, Mattioli G, Romano C. Pediatric gastric volvulus: diagnostic and clinical approach. Case Rep Gastroenterol 2013;7:638.

14. ParkWH, Choi SO, Suh SJ. Pediatric gastric volvulus: experience with 7 cases. J Korean Med Sci 1992;7:258-63.

15. Singal AK, Patel R, Jain S, Gavhane J, Kadam NN. Laparoscopic management of neonatal gastric volvulus: a case report and review of the literature. Eur J Pediatr Surg 2009;19:191-3.

16. Al-Salem AH. Acute and chronic gastric volvulus in infants and children: who should be treated surgically? Pediatr Surg Int 2007; 23:1095-9. 